\title{
The parish as existential space: A theological critique of territory
}

\author{
Sigurdson, Ola \\ University of Gothenburg, Sweden \\ ola.sigurdson@lir.gu.se
}

\begin{abstract}
In this article I call for a reconceptualization of space in relation to the ecclesial parish system through differentiating between "space", "place", and "territory", suggesting that the last term has been instrumental in introducing an ideological notion of space - in short, the reduction of place and space to administrative territory - into the ecclesiological self-understanding of the Church of Sweden. For my analysis of "territory" as an ideological notion and for a more productive understanding of what I call "existential space", I refer to contemporary spatial theory in philosophy. The object of study is several paragraphs in the statutes of the Church of Sweden. Several empirical examples - the suburban areas of Rosengård and Flemingsberg - help to further the analysis and substantiate my theoretical argument. Finally, I offer some thoughts toward a more constructive theology of space than that provided by the territorial understanding of the parish. Although concerned with the understanding of parish within the Church of Sweden, the ultimate aim of this article is to contribute to a more general discussion of theological understandings of spatiality.
\end{abstract}

\section{Keywords}

Administrative territory, existential space, parish and territory, space and ideology, space and religion, theology of space, urban theology

\section{Parish and territory}

In the official statutes of the Church of Sweden, The Church Ordinance of the Church of Sweden [Kyrkoordning för Svenska kyrkan], chapter 2, $\$ 1$, establishes that the "parish is the local pastoral territory" and that the "parish is responsible for the ecclesial functions for all who reside in the 
parish". ${ }^{1}$ We may begin by noting that "parish" is understood in two ways in this passage: as identified with a particular territory, and as an agent able to take responsibilities upon itself. Although this tension between parish as territory and parish as agent acting in its own territory is hardly a fatal consequence of the way the principle is formulated, I believe it might serve to conceal, somewhat, the distinction: it allows for a certain oscillation between agency and area, where the dynamic nature of the church is hidden, as it were, behind a static understanding of territory as a flat surface whose purpose is purely administrative.

The parish system has a long history in Sweden and elsewhere. From 1536 until 2000, the Church of Sweden was a Lutheran state church, though the history of the Swedish parish system precedes the establishment of a national state church during the Reformation. ${ }^{2}$ However, one may still suspect that the identification of the territory of the state church with the borders of the nation state led to a certain emphasis on territory as such, or perhaps to a transformed understanding of the territory involved in the parish system. One reason why the parish system was established long ago was no doubt administrative: There was a need for a principle for distributing responsibility, and two-dimensional mapping in the form of territory lends itself easily to such purposes. Mapping out various local parishes accomplished an overview of who was to be responsible for what. This was not only for the "ecclesial" purposes mentioned in the Church of Sweden statutes, such as distributing the sacraments and preaching the gospel. "Political" and "economic" purposes also played a role: the organization of conscription, taxation, schooling, public welfare (or rather charity) and so on also required the distribution of responsibilities. Not that these other purposes were understood, then, as outside the ecclesial responsibilities, but as distinct purposes; nevertheless, they all called for some principle for distributing responsibilities.

1 Kyrkoordning 2014, chapter 2, § 1; in Swedish: "Församlingen är det lokala pastorala området. ... Församlingen har ansvar för den kyrkliga verksamheten för alla som vistas i församlingen".

2 On the medieval roots of the Swedish parish system, see Nilsson 2001:98-111. For an account of its modern transformation, see Bexell 2003:211-245. 
When established, territory also meant more than administration. Territory was established on the assumption that those inhabiting or residing in a particular territory belonged together in a community where the sum was more than its parts, not merely an assemblage of individuals, as the parishioners' lives were interwoven. This means, among other things, that the particular territory was of existential import to its inhabitants, perhaps not only because of other people but also because of the environment, including the natural and cultural milieus (i.e., the landscapes as well as the buildings). British social scientist and geographer Doreen Massey writes that one characteristic of the history of modernity is "an assumption of isomorphism between space/place on the one hand and society/culture on the other. Local communities had their localities, cultures had their regions and, of course, nations had their nation-states". ${ }^{3}$ There is therefore a certain assumption of "spatial coherence" that more or less took for granted two things: first, that the divisions of territory were somehow already there from the beginning and, second, that they corresponded to some kind of cultural, ethnic, and/or religious homogeneity. Such notions of "spatial coherence" are active even today, but Massey regards them as nostalgic, domesticating, and potentially imperialist. There never was such coherence, Massey suggests, but the image of it easily serves disciplinary purposes. Indeed, I think she is right: the parish system of ecclesial organization has no doubt, even before modernity, contributed to the early modern project of organizing national territory. It might well be that early modern endorsers of the parish system were actually more aware of "spatial discordance" than the image of "spatial coherence" allows for; be that as it may, in early modernity the "assumption of isomorphism" was at least relatively easier to make in many places than it is today, given the current pluralization of societies.

\section{Existential space}

Nevertheless, as I have already suggested, I think that there is more to the parish system than spatial coherence. Returning below to the actual and potential threats of a territorial imagination, I would suggest that the way territory was conceived as space/place in the parish system also

3 Massey 2005:64. 
serves some legitimate existential purposes. Like Massey, I think that the existential importance of space/place calls for a reconceptualization of how we understand space/place, but all I want to suggest here is that the parish system, as it was rolled out long ago, served not only administrative and/or disciplinary purposes. It also found a resonance in the almost irreducible existential importance of spatiality as well as locality for human existence. Like Massey, I also think that "space" and "place" belong together. More about that soon.

What do I mean by the "existential importance" of space and place? One way of understanding this is to associate it with "rootedness". Although I am not against all senses of "rootedness", this might well come to mean precisely such an isomorphism between space/place and society/culture as Massey mentions in the above quotation. What I mean by "existential importance" is, however, something different. To begin with, it implies an active relationship between the inhabitant and the space and place inhabited. "Space" is not just a certain physical area or a certain territory that is "just there", but something that emerges and is created through its "use", "employment", or even "cultivation". Rather than just saying, for example, that we live "in" a home, a better way of expressing this relationship is to say that we "inhabit" our homes, because this way of putting it emphasizes that the activity of inhabiting a home is a process that takes time. After moving to a new accommodation, it takes some time to make this accommodation into a home (if we ever succeed, that is), transforming it from a mere physical container. This point is well put by the French philosopher Gaston Bachelard in his classic book The Poetics of Space: "A house that has been experienced is not an inert box. Inhabited space transcends geometrical space". ${ }^{4}$ The act of inhabiting a space is a poetic act in the etymological sense of the word, namely, a creative or formative act.

This has also come to the attention of Maurice Merleau-Ponty, one of the most renowned French philosophers in the tradition of phenomenology, who has written extensively on embodiment and spatiality in his book Phenomenology of Perception. In a chapter entitled "Space", he claims that for a human being as a living being, existential space precedes geometrical 
space. The latter is rather an abstraction that becomes possible if we take a step back (metaphorically speaking) from the act of inhabiting a certain space to attempting to measure it. Even the act of measuring space takes place because we think that we are able to inhabit space more effectively if we also conceive it as geometrical space. As Merleau-Ponty writes, however, "to experience a structure is not to receive it into oneself passively: it is to live it, to take it up, assume it and discover its immanent significance". ${ }^{5}$ This gives a first introduction to what I speak of as "existential space": it is simply the more or less tacit presupposition of spatiality for human beings as spatial beings, existential rather than geometrical because it is always already imbued with meaning. Even if our own personal act of inhabiting a certain space constitutes an active relating to this space, this does not mean that such a personal act takes place unhindered by others nor that we are starting from scratch. Our spaces are always already inhabited - or at least used - in one way or another. This means, among other things, that our spaces are parts of what constitutes us as human beings, i.e., the way we relate to our spaces expresses something of who we are and what we aspire to be. I am almost tempted to suggest that space is an extension of human embodiment, although such a statement does not quite capture the dialectic between the intimacy of our belonging to and the actuality of our distance from space. Nor does it suffice to suggest that space "means" a lot to us, because such a suggestion might reduce the status of space to a conscious affective-cognitive relationship.

I have used "home" to illustrate the existential importance of space, but this is just one example. Mutatis mutandis, it is also possible to speak of "place" in a similar way. In a book, Faith \& Place, addressing precisely this question, the British philosopher of religion Mark R Wynn suggests that there is always already an existential relationship to "place", a relationship that he denotes with the noun "responsiveness": "Knowledge of place consists, at least in part, in an embodied, practical and, very often, theoretically inarticulate responsiveness to a given region of space". ${ }^{6}$ Wynn's autobiographical account of such places includes a meadow and a cloister in Oxford as a part of its "emotional geography", but I see no principal argument why other

5 Merleau-Ponty 1992:258.

6 Wynn 2009:8. 
such accounts might not replace meadows and cloisters with more urban or suburban surroundings. ${ }^{7}$ It is no coincidence, however, that Wynn (much like Bachelard) uses an autobiographical account for his philosophical reflections on place; only in this way can the affectively and experientially laden nature of the knowledge of existential space be made clear. The use of an autobiographical account should not entice us to think that this existential relationship to place is merely subjective. There is a genuine relationship between place, and us; so in a certain sense it is possible to ascribe agency to place, according to Wynn. There is nothing mysterious about such agency, as it concerns what has occurred at a certain place, a history that is narratively mediated: "a place may elicit a certain kind of practical response because of the role of its history in fixing the sense of the behaviours which are performed there". ${ }^{8}$ Thus, we are shaped (but hardly determined) by the places that we inhabit in a thoroughgoing sense, as they influence our very embodied comportment. Even our relationship to God is not independent of place in that it is mediated through body, place, and space. ${ }^{9}$

We have already encountered distinct usages of "space" and "place", and so a need for conceptual clarifications of these has appeared, at least with regard to how I use these concepts. At the same time, however, these are the contested concepts in this article, so a more profound understanding of them will hopefully, be the end result of its entirety. I have already mentioned that I agree with Massey that they belong together. ${ }^{10}$ Intimately so, I would suggest, in that they (as I use them) point to different aspects of the same phenomenon. If "place" denotes locality, it is used to point out that a "here" or "there" is necessary for something to take place; "space", on the other hand, is more about the possibility, the "where" so to speak, for something to take place. To put it negatively, in terms of the discussion I will be having in this article, "space" is not a container and "place" is not a map. I will alternate between using "space" and "place" in my discussion

\footnotetext{
7 Wynn 2009:19.

8 Wynn 2009:71.

9 For an extended argument about human embodiment and the relationship to God, see Sigurdson (forthcoming 2016).

10 Massey 2005:5-8.
} 
below, depending on which aspect I wish to point out but also in relation to whatever usage I find in the authors I discuss. Yet "space" will be the master concept of this pair in this article, as I here wish to emphasise possibility more than actuality.

Further, I use the term "existential" to describe our relationship to home, place, and space to draw our attention to its embodied, affective, and experiential nature. "Existential" should not be misunderstood as standing in contrast to "social" or "political", however; "existential" does not here mean "private", "subjective", or "existentialistic". "Existential" refers to what is of ultimate concern to us as human beings, and includes the physical as well as the mental, social, and spiritual aspects of our existence. When I speak of "home" and "place", these should not be understood as just existing alongside, for instance, public space. Public space is the space we inhabit, employ, and perhaps even enjoy together with others, and as such it also influences what we call home and our experience of places salient to us. "Public space" is also an existential space in that we have embodied, affective, and experiential relationships to it. My intention in introducing the concept "existential space" is not to mark out or privilege any particular space, but simply to emphasize the existential nature of our relationship to space. To the extent that we reductively imagine space as a container, enclosing all our actions, longings, relationships, et cetera, but not interfering with them as such, there is a need to call attention to how our existence is spatial in a more direct sense and how space is of direct existential concern to us. But if space is not a container, what is it?

Massey has offered a three-tiered definition of space that is helpful in understanding existential space as public space and as home and place. The three dimensions of space are: (1) "space as the product of interrelations"; (2) "space as the sphere of possibility of the existence of multiplicity in the sense of contemporaneous plurality"; and (3) "space as always under construction". "The first aspect of space is that it is not just a container within which we move and interact but rather is produced by interaction between human beings and by their interaction with the non-human environment, living or non-living. Even the relationship to God is, from

11 Massey 2005:9. 
a theological perspective, productive of space in that it concurs and conflicts with all other relationships. The second characteristic tells us that inhabiting space is not necessarily a zero-sum game in which there is room for only one way of inhabiting space at a time. "Contemporaneous plurality" means that several things can go on at the same time in the same space. This does not mean, obviously, that conflict cannot occur but rather that the condition of possibility of conflict is this "contemporaneous plurality". That space, thirdly, is "always under construction" means that space cannot ever become a finished project. As space is a product of interrelations rather than an empty container, space is being produced as long as human beings interrelate and is not so much a thing as an ongoing process. Space is a "social construction", then, not a social construction in the purely cognitive sense (and surely not in contrast to material reality) but a construction of the very real matter-of-fact social interactions that go on whether we think about them or not - including, of course, affective and cognitive dimensions.

I suggested at the beginning of this section that such an understanding of space is a reconceptualization of space, and I assume that some may find this counterintuitive. The reason for this counterintuitiveness, I would suggest, is to be found in the pervasiveness of the container version of space. It is taken for granted that the dimensions of space can be measured geometrically and that these geometrical measures are somehow foundational for the way that space works, more foundational than the existential or social meaning or status of space. There are at least two reasons why space as commonly perceived is reduced to geometry. One is phenomenological. Much like the body, space is an inevitable condition of our existence as embodied, social beings and, as such, it is usually taken for granted except when it is dysfunctional or when we consciously decide to reflect on it. The attentiveness of the human consciousness is directed towards fulfilling our projects or towards the human or non-human surroundings that claim our attention, putting many of the preconditions of this attentiveness in the shade. Only in some exceptional states of consciousness, perhaps, are those preconditions thematized. The other reason why space is often reduced to a geometrical understanding is ideological. Ideology, here, concerns questions of who has the power to define space or whose purposes or ideas 
space realize space. ${ }^{12}$ As I will demonstrate in the next section, one of the most powerful ideologies of Western society today is the understanding of space as an administrative territory, in effect reducing three-dimensional existential and social space to two-dimensional territory. Ideology exploits the relative invisibility of phenomenologically understood space to homogenize it, gaining the benefit of appearing natural. Let me now turn to the question of ideology in the form of administrative territory.

\section{Administrative territory and existential space}

As I mentioned at the beginning, there is a certain ambiguity in the notion of the parish in The Church Ordinance of the Church of Sweden, being on the one hand an agent, and on the other an area. I have also argued that place does not necessarily mean only an area or territory circumscribed for administrative purposes, but that any place also might be of existential importance to those living in it. For much of the history of the parish system, we can assume that this existential importance was dependent on a presumed isomorphism between space/place and society/culture, as Massey suggests. A certain place is associated with a certain character of social existence and of nature. However plausible such an isomorphism might have been earlier in history - and we might surely harbour doubts about that - through the processes of (late) modernization, such isomorphism has inexorably been diluted. Late modern differentiation, pluralization, and urbanization have drawn apart any association of a particular place with a particular social and cultural meaning, except, perhaps, for marketing purposes. This does not mean that places today are not existentially salient, only that there is hardly any single existential importance of place. In accordance with Massey's second characteristic of space, I suggest that the "contemporaneous plurality" of almost any particular space is much more obvious today than before. For the parish system, this means, among other things, that its place is not as isomorphic with a certain religious belonging as it used to be (at least relatively speaking). The place in question might still be of religious or existential importance to those inhabiting, passing through, or working in it, but this importance now assumes many different

12 Lefebvre 1991: "Ideology per se might well be said to consist primarily in a discourse upon social space” (p. 44). 
if not conflicting shapes. ${ }^{13}$ It can no longer be taken for granted that someone born in a parish in Sweden is baptized, as statistics tell us that the frequency of baptism has declined from $76.2 \%$ of the population in 1980 to $56.0 \%$ in $2010 .{ }^{14}$ The decrease in baptism frequency illustrates this pluralization of space that has taken place through (late) modernization. This is not to say that space/place was not plural before; indeed, the parish system might have been instrumental - especially combined with a state church system - in making the religious diversity of a given space more or less invisible. What I am suggesting is that the isomorphism that could be taken for granted earlier is no longer plausible.

What does this mean for our understanding of territory in the parish system? If the existential importance of a given space/place is no longer one but many, then territory cannot be understood as an existential space based on the premise that the "parish [as agent] is responsible for the ecclesial functions for all who reside in the parish [as area]". ${ }^{15}$ Being "responsible for the ecclesial functions" means, I take it, somehow drawing the residents into the existential space of the ekklesia through the rites of baptism, confirmation, marriage, and funeral (those are mentioned in the ordinance). However, the parish is responsible not only for ecclesial rites but also for providing worship, teaching, ministry, and mission. As there is significant plurality in most modern parishes, many of their residents do not wish to partake in this existential space nor would they entertain any wishes that the parish make itself responsible for their religious or existential wellbeing. Of course, there is room for middle positions between those actively committed to the ecclesial existential space and those not committed to it: some make use of the ecclesial rites but interpret them in their own way, some make use of them out of a sense of cultural tradition rather than religious commitment, and some want to be committed but just cannot find the time. Indeed, middle positions have always existed, but the pluralization of existential space means that the distance between those committed and those not committed has increased. To many residents of a particular parish, ecclesial existential space is no longer meaningful

13 The literature on religious transformation is vast, but see Casanova 1994.

14 Matrikel 1996:498; Matrikel 2014:454.

15 Kyrkoordning 2014, chapter 2, \$1. 
and the ecclesial responsibility pointless. To sum up the argument in this paragraph: I have been suggesting that the ambiguity of the relationship between the parish as agent and the parish as area has increased through pluralization, sometimes to the point of breaking.

At a point in history when a relative isomorphism between the parish as agent and as area could be assumed, there was no particular need to negotiate this ambiguity, but as these two poles have grown apart, the parish is put in a dilemma: on the one hand, giving up its agency would mean divesting itself of any recognizable character as a Christian ekklesia; on the other hand, the parish still needs to negotiate this agency with a responsibility for a certain territory that encompasses many different existential spaces. As neither the wish nor the means exists to (re)establish cultural, social, or religious hegemony over these existential spaces, the solution will inevitably be to dissociate place in the sense of territory from existential space. If an earlier understanding of the parish meant that territory or place was associated with a certain understanding of existential space, the dissociation of territory from existential space means that territory will now be reduced to a flat and static notion of place. Territory is currently understood in more administrative terms; territory will come to assume a strictly geometric or cartographic meaning.

The French Marxist philosopher and sociologist Henri Lefebvre in his classic The Production of Space has described precisely such a dissociation of what he calls social space from abstract space (a process that extends far beyond the parish system): "abstract space relates negatively to that which perceives it and underpins it - namely, the historical and religio-political spheres". ${ }^{16}$ Such a dissociation results in the juxtaposition of an active, spaceless agent and a passive, transparent, and empty space that is nothing other than a container for the actions of agents - similar to the Cartesian distinction between res cogitans and res extensa. Social space, the space produced through the interaction of people, does not disappear but becomes invisible and the container-like space becomes naturalized and taken for granted. It is not as if space is abstract; it is only represented as such in a way that hides its social production from view. As a representation, however,

16 Lefebvre 1991:50. 
abstract space or territory does have an impact on how space is produced in its use: 'It has nothing of a 'subject' about it, yet it acts like a subject in that it transports and maintains specific social relations. It functions positively vis-à-vis its own implications: technology, applied sciences, and knowledge bound to power". ${ }^{17}$ In other words, abstract space, because of its generalizing trajectory, functions in a homogenizing way. In my example using parishes as territory, their representation as two-dimensional space creates the illusion of a view from above flattening, as it were, all social and existential - and therefore multidimensional - relationships. Place as territory is no longer associated with particular relationships but constitutes something one can draw on a map. This represents the striving for overview, power, and control of a particular area, far from the messiness of what Massey calls a "space ... always under construction". Abstract space, then, is hardly innocent of power. On the contrary, it is a way of managing power over space, "a property which guarantees its social and political utility", as Lefebvre puts it. ${ }^{18}$ Again, it is not homogenous; it is only represented as such, as the goal towards which it is striving.

\section{Rosengard and the politics of leaving}

An excellent illustration of the consequences of reducing the parish to a geometrically understood administrative territory is provided by the Swedish art historian Henrik Widmark in an article entitled "Space, Materiality and the Politics of Leaving: The Church of Sweden and the Social Segregation of Rosengård". ${ }^{19}$ In this article, Widmark describes a suburban part of Malmö, Rosengård, once seen as an epitome of Swedish modernity, "a modern Florence shaped in welfare". ${ }^{20}$ However, as the industrial fortunes of Malmö declined, the image of Rosengård has shifted from a positive one towards "segregation, anonymity and dissolution", as Widmark puts it: "When immigrants became the majority of Rosengård, a not always well-disguised xenophobia changed Rosengård from a problem

\footnotetext{
17 Lefebvre 1991:50.

18 Lefebvre 1991:285.

19 Widmark 2010:49-64.

20 Widmark 2010:49.
} 
area into ... a space of harmful difference". ${ }^{21}$ Instead of being seen as an expression of progress and prosperity in the modernization of Sweden in the 1960s, a part of the modern city, Rosengard became estranged from other parts of Malmö. As Widmark illustrates, Rosengård has been a place of ongoing riots and arson, and since the 2000s has figured in Swedish media as an example of a suburb gone awry.

What connects Rosengård to the present discussion is that the Church of Sweden was part of the Rosengård project from its inception together with the municipality and commercial actors. A district church, the Rosengård church, was built in the centre of Rosengard and, together with the other actors, it hoped to establish a new, modern society. The district church of Rosengård was part of the Västra Skrävlinge parish, rooted in a historical municipality of the same name. The main church of this parish goes under the same name as the parish, and is a nineteenth-century building located on the other side of Inre Ringvägen, a road that both geographically and symbolically separates Rosengård from the rest of Malmö, including Västra Skrävlinge. In 2014, the parish of Västra Skrävlinge was included in the parish of Fosie. The parish of Västra Skrävlinge was the parish in the Church of Sweden with the smallest percentage of church members. One reason for this is that Rosengard formed most of its territory, and Rosengård is one of the most multi-religious suburbs of Sweden, with more than $86 \%$ of the population being of foreign background. Even though the attendance of services in the Rosengard church was low, the church served another purpose according to Widmark, namely, symbolizing the presence of Swedish society in Rosengård.

When the Rosengård church was closed on Wednesday, 15 March 2000 and the building deconsecrated, the residents of Rosengard understood this even though most of them did not belong to the church - not just as an administrative measure in light of the poor attendance. It was understood as a withdrawal of Swedish society - associated with the district church from Rosengård, which was no longer included in wider society but rather excluded from it. From the point of view of the church and its understanding of the parish as area, as an administrative territory, Rosengård was of course

21 Widmark 2010:51. 
still included in Västra Skrävlinge parish. Considering that the Rosengård church was within acceptable if not convenient walking distance of the Västra Skrävlinge parish church, from just looking at a map the closure does not appear to be that significant. Given that the Inre Ringvägen road symbolically separates Rosengård from the rest of Västra Skrävlinge and Malmö, however, it is clear that although the district church and parish church in some sense shared a two-dimensional area, they did not inhabit the same space. The closure of the Rosengård church became, in Widmark's words, a political act of leaving, which also meant "an act of redefining the church of Sweden, the parish of Västra Skrävlinge, and the space of Rosengård". ${ }^{22}$ From the perspective of understanding space as existential and social rather than merely abstract, the deconsecration of the Rosengård church was understood as a withdrawal from one of the most marginalized suburbs of Sweden. As Widmark puts it:

By being inside the centre, Church of Sweden made a political statement of belonging - and as a church it is essential to show the presence as a worshiping community and through its symbolical representation in the church building. Leaving the centre underlined the boundaries in Swedish society; it emphasized Rosengård's social segregation; it made the uneven geography of society more evident. ${ }^{23}$

The presence of the Church of Sweden could not be understood only as representing Swedish civil society, as the celebration of mass and worship potentially and actually transformed the way space is inhabited in this particular location. Although the vast majority of Rosengård residents did not participate in this church's gatherings, the presence of the church helped negotiate the relationship between Rosengard and the space of Swedish civil society as well as the global church in an act of symbolically inhabiting the suburban centre of Rosengård.

This act of leaving, says Widmark, is based on the presupposition of an isomorphism between space/place and society/culture, a presupposition that is simply no longer valid. A flat map no longer tells us anything about the different spaces separated by a main road, nor does it help us understand

22 Widmark 2010:52.

23 Widmark 2010:56. 
the "contemporaneous plurality" of ways of inhabiting space. Widmark's article suggests that locality and space are indeed of continuing relevance to the Church of Sweden, but that the reduction of space and place to territory representable on a two-dimensional map serves to conceal rather than reveal how space is actually inhabited by current and potential members of the church. By the act of leaving, the Church of Sweden lost an opportunity to be part of the identity space of Rosengård; in contrast to several mosques and the St. Mary's Roman Catholic Church, the Church of Sweden is no longer part of the spatial imaginary of Rosengard, despite the claim that Rosengård first belonged to the territory of Västra Skrävlinge parish and now belongs to Fosie parish. Imagining the parish as area or territory laid out for administrative purposes exposes the church to the risk of not adequately understanding its own actions. The Church of Sweden chose to go into voluntary exile, leaving Rosengård behind, at the same time as it actually imagined itself staying. This one example of the reduction of the parish to a flat territory has serious consequences - although possibly unintended.

In the interest of fairness, let me close this section by saying that this is not the end of the history neither of Rosengard nor of the Church of Sweden's involvement with the suburb. The image of Rosengård has recently been modified from the more riotous one communicated by the mass media, as the world-renowned Swedish footballer Zlatan Ibrahimoviç has told his story of growing up in Rosengård and the FC Rosengård football team won the Women's premier division in 2014. ${ }^{24}$ In addition, the Church of Sweden, although not currently having an actual church building in the area, is again involved in this space, productively and perhaps also in a visionary way. ${ }^{25}$

\section{Flemingsberg parish and the distinction between strategy and tactic}

Let me now turn to another illustration of the same tension between the parish as geographical territory and as existential space. This time we will concern ourselves with Flemingsberg parish in Stockholm, the subject of

24 Ibrahimoviç 2013.

25 For more about Rosengård, see Aldén 2013. 
a 2009 dissertation by Swedish theologian Jonas Ideström: "Local church identity - a study of implicit ecclesiology with the example of the Church of Sweden in Flemingsberg" would be the title of this dissertation in English. ${ }^{26}$ Flemingsberg is a southern suburb of Stockholm, located in Huddinge Municipality, with around 12,000 inhabitants, around the same number of people working there, and another 13,000 students at Södertörn University College. It is home to part of Karolinska University Hospital and other prestigious research institutions, to a police station, a courthouse, and a jail, and to a number of high-rise residential buildings. In short, Flemingsberg is a typical suburban area with many people commuting into and out of it daily. The dissertation is an ecclesiological study applying an ethnographic method, and Ideström concerned himself with uncovering the "implicit ecclesiology" of Flemingsberg parish as manifested in observations, interviews, and documentary research conducted between March 2005 and March 2006. Much can be learned from Ideström's dissertation, but of central concern here is how he lays bare a tension between, on the one hand, a more defined social body consisting of either those employed by the parish or those celebrating mass and worshipping together and, on the other hand, a social body lacking any definitive boundaries, where the territory of the local parish coincides with the administrative area of the local municipality. Depending on which is the focus of the sub-studies presented in the various chapters of the thesis - i.e. the parish church as a building, the church service, or the territorial area - the social embodiment naturally differs in appearance, but on the whole, Ideström tracks a tension similar to that between what I here call agency and area.

Ideström interprets this tension through the lens of the French historian and Jesuit Michel de Certeau's distinction between "strategies" and "tactics". I will explain these two concepts in some detail, before returning to Ideström's use of them. A strategy, according to de Certeau in The Practice of Everyday Life, is "the calculation (or manipulation) of power relationships that becomes possible as soon as a subject with will and power ... can be isolated". ${ }^{27}$ This subject reigns over an area: "It postulates a place that can be delimited as its own and serves as the base from which relations

26 Ideström 2009.

27 de Certeau 1988:35f. 
with an exteriority composed of targets or threats ... can be managed" ${ }^{28}$ De Certeau calls this a "Cartesian attitude", which is "the typical attitude of modern science, politics, and military strategy". ${ }^{29}$ It has a panoptic perspective in that it tries to achieve an overview of the place it calls its own, assuming this to be a perspective of power over the area in question. As should be clear, the place of a strategic perspective is analogous to what I have called abstract space. In contrast, "a tactic is a calculated action determined by the absence of a proper locus". ${ }^{30}$ As it does not have a place of its own, "it must play on and with a terrain imposed on it and organized by the law of a foreign power". ${ }^{31}$ A tactic, then, is defined by the absence of panoptic power: "It does not, therefore, have the options of planning a general strategy and viewing the adversary as a whole within a [distinct], visible, and objectifiable space". ${ }^{32}$ This means that a tactic cannot, like a strategy, form a plan of action that it is determined to implement, but rather must react or make do with whatever the circumstances present. In the same book, de Certeau has given a very powerful illustration of the difference between strategies and tactics with regard to spatial practices, as in the contrast between looking out over Manhattan from the 110th floor of the World Trade Center (the book was published in 1980) and the more pedestrian activity of walking in the city. ${ }^{33}$ Whereas the strategic subject sees Manhattan spread out before his or her panoptic eye, the pedestrian finds him- or herself in the quotidian hustle and bustle of life in the streets and avenues of Manhattan.

Doreen Massey has rightly pointed out that de Certeau, through his sharp distinction between strategies and tactics, is caught in the very binary dualism that his book wishes to avoid. ${ }^{34}$ It is not all or nothing, we might say: in viewing Manhattan, we need not choose only between the top of the skyscrapers and ground level. It is not about power or no power at all. Against de Certeau's distinction interpreted in a binary way, I would like

28 de Certeau 1988:36.

29 de Certeau 1988:36.

30 de Certeau 1988:36f.

31 de Certeau 1988:37.

32 de Certeau 1988:37.

33 de Certeau 1988:91-93.

34 Massey 2005:26, 45-47 
to suggest that power can be distributed in a more differential way and that even though a Cartesian, panoptic perspective might be active on the level of representations, it is not to be identified with the level of actual practice. Nevertheless, de Certeau's distinction still serves to illustrate the tension in which the parish of Flemingsberg is caught (along with other parishes). In relation to its social context, Flemingsberg parish appears as a strategic agent with an overview of its geographical territory - identifying itself as one of the dominant agents with the power to define Flemingsberg as a place - but now as an alternative social embodiment that needs to act tactically in relation to other agents, especially regarding its services in hospitals and prisons and in its own local church. Moreover, Ideström points out that its attempt to appear as a strategic agent takes place even though it actually lacks the power and mandate that is needed to act strategically in relation to the suburb of Flemingsberg: "The local church is not a dominant agent with the power to uphold the area of the geographic parish as its own territory". ${ }^{35}$ Such dominant agents are instead the municipality and the county, as well as the businesses and research institutions in the area, but of course only relatively so: they too must respond to circumstances outside their control. The various perspectives of the parish also imply various eschatologies: while the strategic tendencies tend to downplay any futural aspects of eschatology in their attempt to control the future, the tactical tendencies emphasize the futural aspects of the presence of Christ, the ever-present possibility of newness happening. The latter perspective is not only more in line with the understanding of space that I outlined above with the help of Massey - i.e., space as the product of interrelations, as "contemporaneous plurality", and as "always under construction" - but also appears more conducive to what makes the church a distinctive social body, namely, its status as a creation of the divine Word, with its own distinctive telos and eschatology, not just another administrative unit in the public sector.

Ideström's dissertation provides an important illustration of how the tension between the parish as agent and as area is worked out in a particular case. This case is likely far from uncommon, but rather quite representative of what contemporary suburban parishes experience in a culturally and religiously plural context. It also gives some empirical flesh to my historical hypothesis

35 Ideström 2009:264. 
articulated above, namely, that administrative territory came to replace the earlier geographically understood existential space of the parish when the isomorphism between space/place and society/culture became increasingly implausible. Finally, Ideström also makes it clear that the understanding of administrative territory is still significant for the self-understanding of the local parish at the same time as it creates tensions that are likely theologically unresolvable in this particular representational scheme.

\section{The responsibilities of space}

How, then, should we conceive of a more constructive theology of the parish? I regard the challenge as not getting rid of the parish system altogether, but rather of re-conceiving the understanding of space implied by it. As I have demonstrated, the understanding of space/place as administrative territory is not the only possible conception of space, and as place and space carry existential meaning, it would be counterproductive to try to imagine Christian congregations without any relationship to space at all - indeed, other conceptions than the parish system are possible, but perhaps the parish as such holds promise if it can uphold a relationship to tradition at the same time as it orients itself towards how space is inhabited today. As Lefebvre rhetorically asks (although identifying religion with ideology): "What would remain of a religious ideology - the Judaeo-Christian one, say - if it were not based on places and their names: church, confessional, altar sanctuary, tabernacle?"36 I would not go as far as suggesting that the Christian church is based on places, but rather that it is related to places, and in many ways strongly related to places. In other words, the Christian church needs to take place, as it is always already socially embodied in some way (whether in the parish form or not), but as there are many ways of being embodied or taking place, what is needed is a theology of space/place that does not reduce space to something depicted on a two-dimensional map. Instead, a constrictive theology of space needs to recognize the three dimensions of spatiality suggested by Massey: space as the product of interrelations, as "contemporaneous plurality", and as "always under construction". This final section will offer some thoughts on what a constructive theology of space/ place might be like from the perspective of a parish system.

36 Lefebvre 1991:44. 
Let me begin with the etymology of the term "parish". Etymology is not, of course, destiny, and such an etymology would not work in any language. ${ }^{37}$ Nevertheless, it is interesting to note how the term itself suggests another understanding of inhabiting a space than unequivocal rootedness. The term "parish" is derived from the ancient Greek paroikia, which means "the stay or sojourn of one who is not a citizen in a strange place, also the foreign country itself", but also "congregation, parish ... in so far as it represents a community of such 'strangers". ${ }^{38}$ The term "paroikia", in its turn, is derived from paroikos, which means "stranger, alien, one who lives in a place that is not his home". ${ }^{39}$ Compared with the OED's definition of "parish", this is the opposite of what the dictionary takes to be the meaning of the English term, namely, "the body of people who attend a particular church; the inhabitants of a parish" but also "an area or district having its own priest, parson, or other incumbent under the jurisdiction of a bishop ...; a territorial subdivision of a diocese". The meaning of the term seems to have evolved from "strangers" to "residents", and it is not difficult to understand why. With the gradual historical establishment of the Christian church and, even more, the national churches as a part of public life in Europe, the isomorphism of space/place and society/culture has increased and the experience of being aliens in a foreign land has decreased. If this isomorphism is now becoming increasingly less credible, for example, in Sweden, shedding the ideology of abstract place or administrative territory might imply that there is reason to revive the understanding of the parish as a gathering of strangers or sojourners. This is not as a nostalgic return to some "pre-territorial" condition - such nostalgia is for many reasons unproductive - but as a negotiation within a space where there are many contemporaneous and even competing ways of inhabiting this space and where any claim of church hegemony is illusory, at best.

Let us return to The Church Ordinance of the Church of Sweden to look at some of its ideas of how the parish is defined, beginning with "responsibility". The very idea of having a responsibility for "the ecclesial functions for all who reside in the parish", as the ordinance puts it, assumes

37 The Swedish term for "parish", "församling", simply means "gathering”.

38 "paroikia", A Greek-English Lexicon 1979.

39 “paroikos”, A Greek-English Lexicon 1979. 
a position of relative power, a more or less permanent place from which such a responsibility can be discharged. This does not mean that "strangers" are, as such, "irresponsible", only that responsibility presupposes power in the sense of having the capacity as well as the means to realize it. Responsibility, then, presupposes another relationship to space/place than just being a guest or an occasional visitor. Perhaps if we conceive of space as the product of interrelations, rather than as territory, this would suggest how such relative power (through which responsibility can be discharged) is exercised in a way that does not presuppose power as hegemony and control. When the ordinance speaks of the recipients of responsibility, it uses the Swedish term "vistas", which I have translated as "reside", but could also be translated as "dwell" or "sojourn", and the point of the ordinance is that not only those who are registered as living in the area are part of the parish but also, at least potentially, those who visit for work, study, refuge, or other purposes. However, if the parishioners are "sojourners", so is the parish itself a sojourner. This means that the first sentence of the paragraph, "[the] parish is the local pastoral territory", needs to be modified from the direct identification of parish and territory to something that expresses the interrelational and "strange" status of the parish, perhaps "a parish resides in a place for pastoral purposes". The parish, then, is more the agent than the area, and is not defined by territory but by dynamic interrelations among the parishioners.

This would also modify the mild paternalism that potentially lies hidden in the notion of "responsibility". If the parish as such also is a "sojourner" in some sense, then its responsibility is not conceived or practiced as "vertical" (the illusion of panoptic power) but as "horizontal". The "all" for whom the parish is responsible is not a homogeneous residential collective that finds itself the object of pastoral benevolence. Not only are the parishioners the subject of responsibility, in accordance with an interrelational understanding of space, but that responsibility might look very different depending on who is the "other" - not all "others" wish to be recipients of the pastoral concerns of the parish, and that is to be respected, in a spirit of "contemporaneous plurality". The "all" is still important, however, as there is no one who is not, at least potentially, the recipient of pastoral care. The theological ground for this "all" is that the church - and consequently its parishes - does not exist for its own sake, but for the sake 
of the world, and so should prevent the parish from drawing too sharp a distinction between "insiders" and "outsiders". All human beings, whether they chose to belong to the church or not, are already, inside or outside of the domain of the church, the recipients of divine grace through creation and perhaps, in some measure, of redemption as well.

All this is not to say that place is not important to human beings. As mentioned above, Mark R Wynn has suggested that place is important for how we make sense of the story of our lives, but place can also be important in that particular places can have religious significance in and of themselves. We as human beings are embodied creatures, and that embodiment means that we always exist somewhere, in a particular place to which we usually form some kind of attachment, and to deny such locality would be illusory. The denial of locality conjures up quite problematic images of a "cosmopolitan rootlessness" that is hardly an option for most people in the world, not even in its affluent parts. "Place", in this sense, need not be identified with "territory", however. "Place" - the houses, skyscrapers, city centres, meadows, sea, and rocks - is part of the existential and interrelational space and should be regarded as co-constitutive of it. The challenge for the local parish is to find a way to relate to place in a way that does not make it into a possession. One reason that the early church understood itself as a stranger in the world was that it regarded creation, "nature" as well as "culture", as a divine gift, not as a possession. Being a "sojourner", then, is not only a matter of being a stranger in a particular society where the majority is of a different religious persuasion but also, and perhaps foremost, of understanding creation not as a given but as a gift. Even place is not a given but a gift, and parishes' relationship to it is not one of identity but of dwelling. What matters is not place as territory but, as Massey puts it (speaking of radical politics), "grounded, practised, connectedness". ${ }^{40}$ Place and space are not opposites, because place as the local environment is included in all the relationships that constitute the existential space of the parish. One may even suggest - as the example of Rosengård above clearly illustrates - that actual place matters more to such an interrelational understanding of space than to a reduction of it to an administrative territory.

40 Massey 2005:187. 
The ultimate ground of interrelational space is to be found in God's own being, according to the Swiss theologian Karl Barth. Against a tradition that has understood God as non-spatial, Barth forcefully argues for God's spatiality understood as interrelationality: "Non-spatiality means existence without distance, which means identity". ${ }^{41}$ But God, according to Barth, possesses space in a way that transcends all created spaces, and can therefore be in relation even in his own being while also creating space for his own creation, including human beings: "God is spatial as the One who loves in freedom, and therefore as Himself". ${ }^{42}$ Therefore, God is also free to have distinct and differential relationships to particular places and spaces; God's presence is never uniform, but it is in and through this differential presence that God is present everywhere. One may suspect that a nonspatial understanding of God has contributed to an abstract understanding of created space through history; conversely, one may also think that an abstract understanding of space has been a cause of the non-spatial understanding of God, as it would hardly do to think of God's divine space as a container. According to Barth, space is indeed the product of interrelation. Consequently, although Barth himself does not dwell on spatial theory, created space should also be understood as "contemporaneous plurality" and as "always under construction" as the condition of created freedom and love. From a Barthian theological perspective, space is the condition of being able to love in freedom, because if there is no space, there is no distance and, consequently, there are no relationships. These - in a more direct sense - theological considerations could and should be developed in much more detail; my purpose in introducing them here is only to suggest that the question of space in theology is not adiaphora or indifferent. The question of space has to do, ultimately, with how we conceive of God and God's loving relationship to creation, human and non-human.

My present critique of territory should not, then, be interpreted as an argument against the parish system. Indeed, I think that much of what is going on in parishes today in terms of pastoral concerns is important and definitively legitimate from a theological perspective. My argument has been against a flawed, reductive, and possibly ideological understanding

41 Barth 1957:468.

42 Barth 1957:470. 
of space in the form of administrative territory. What is needed is a theological reconceptualization of space, one that lets the strengths and not the weaknesses of the parish system be made more clearly visible.

\section{Bibliography}

Aldén, A 2013. Mission I vår tid: Här och nu är allting möjligt. Stockholm: Verbum.

Bachelard, G 1994. The Poetics of Space. Translated by Maria Jolas. Boston, MA: Beacon Press.

Barth, K 1957. Church Dogmatics, Vol. II: The Doctrine of God, Part 1. Edinburgh: T\&T Clark.

Bexell, O 2003. Sveriges kyrkohistoria. 7. Folkväckelsens och kyrkoförnyelsens tid. Stockholm: Verbum.

Casanova, J 1994. Public Religions in the Modern World. Chicago: University of Chicago Press.

de Certeau, M 1988. The Practice of Everyday Life. Translated by Steven Randall. Berkeley/Los Angeles/London: The University of California Press.

A Greek-English Lexicon of the New Testament and Other Early Christian Literature. 1979. Edited by F Wilbur Gingrich and Frederick W.

Danker. Chicago/London: University of Chicago Press.

Ibrahimoviç Z 2013. I am Zlatan Ibrahimoviç. With David Lagercrantz. Translated by Ruth Utbom. London: Penguin.

Ideström, J 2009. Lokal kyrklig identitet: En studie av implicit ecklesiologi med exemplet Svenska kyrkan i Flemingsberg. Skellefteå: Artos.

Kyrkoordning för Svenska kyrkan. Available: http://www.svenskakyrkan.se/ kyrkoordningen [Accessed: 13 November 2014]

Lefebvre, H 1991. The Production of Space. Translated by Donald Nicholson-Smith. Malden, MA/Oxford: Blackwells.

Massey, D 2005. For Space. London: SAGE. 
Matrikel för Svenska kyrkan 1996. Stockholm: Verbum.

Matrikel för Svenska kyrkan. 2014. Stockholm: Verbum.

Merleau-Ponty, M 1992. Phenomenology of Perception. Translated by Colin Smith. London: Routledge.

Nilsson, B 2001. Sveriges kyrkohistoria. I. Missionstid och tidig medeltid. Stockholm: Verbum.

Sigurdson, O Forthcoming 2016. Heavenly Bodies: Incarnation, the Gaze and Embodiment in Christian Theology. Translated by Carl Olsen. Grand Rapids, MI: Eerdmans.

Widmark, H 2010. "Space, Materiality and the Politics of Leaving: The Church of Sweden and the Social Segregation of Rosengård". In: For the Sake of the World: Swedish Ecclesiology in Dialogue with William T Cavanaugh. Edited by Jonas Ideström. Eugene, OR: Pickwick Publications.

Wynn, MR 2009. Faith \& Place: An Essay in Embodied Religious Epistemology. Oxford: Oxford University Press. 